\title{
Teori Humanisme sebagai Dasar Etika Religius (Perspektif Ibnu Athā'illah Al-Sakandarī)
}

\author{
Chairunnisa Djayadin \\ UIN Sunan Kalijaga Yogyakarta \\ Email: chairunnisadjayadinz@gmail.com \\ Fathurrahman Fathurrahman \\ UIN Sunan Kalijaga Yogyakarta \\ Email: fathurr587@gmail.com
}

\begin{abstract}
This study aims to provide a comprehensive and in-depth overview of the results of studying and analyzing the thoughts of Ibn Athā'illah Al-Sakandarī about the theory of humanism as the basis of religious ethics. This research methodology, using the library research method with a philosophical approach, can provide an overview of Ibn Athā'illah Al-Sakandarī's thinking tools about the theory of humanism as a basis for religious ethics as a whole and indepth. The results of the study showed that humanism, in the view of Islam, means to put forward the humanity that applies fairly and lives peacefully amid differences, this is in line with the thought of Ibn Athā'illah based on the Qur'an and Sunnah. Ibn Athā'illah encourages humans to reach the highest level, namely macrifat, where the values of wisdom are a reflection of the theory of humanism as the construction of religious ethics, then Ibn Athā'illah encourages humans to seek knowledge as well as the development of reason. Ibn Athā'illah encouraged humans to develop according to the conditions of the times by not leaving obedience to God. The thought of Ibn Athā'illah was also acceptable in various circles, scientists, workers and so on, besides that with the value of humanism, harmony in society was formed so that Muslims were not in a debate in carrying out his nature as a human being.
\end{abstract}

Keywords: Humanism theory, religious ethics, Ibnu Athā'illah Al-Sakandarī.

\begin{abstract}
Abstrak
Penelitian ini bertujuan untuk memberikan gambaran secara menyeluruh dan mendalam dari hasil mengkaji dan menganalisis pemikiran Ibnu Athā'illah Al-Sakandarī tentang teori humanisme sebagai dasar etika religius. Metodologi penelitian ini, menggunakan metode library research dengan pendekatan filosofis, sehingga mampu memberikan gambaran pemikiran Ibnu Athā'illah Al-Sakandarī tentang teori humanisme sebagai dasar etika religius secara menyeluruh dan mendalam. Hasil penelitian menunjukkan bahwa humanisme dalam pandangan Islam, berarti mengedepankan sisi kemanusiaan yang berlaku adil dan hidup damai di tengah perbedaan, hal ini senada dengan pemikiran Ibnu Athā'illah yang berbasis pada al-Qur'ān dan Sunnah. Ibnu Athā'illah menganjurkan manusia untuk mencapai tingkat tertinggi yaitu makrifat, dimana nilai-nilai makrifat tersebut merupakan refleksi dari teori humanisme sebagai kontruksi etika religius, kemudian Ibnu Athā'illah menganjurkan manusia untuk menuntut ilmu juga pengembangan pada akal. Ibnu Athā'illah mendorong manusia untuk berkembang sesuai dengan keadaan zaman dengan tidak meninggalkan kepatuhan kepada Tuhan. Pemikiran Ibnu Athā'illah dapat diterima oleh berbagai kalangan, ilmuwan, pekerja dan sebagainya. Dengan terwujudnya nilai humanisme dan harmonisasi dalam masyarakat, umat Islam tidak berada pada perdebatan dalam menjalankan kodratnya sebagai manusia.
\end{abstract}

Kata Kunci: Teori humanisme, etika religius, Ibnu Athā'illah Al-Sakandarī. 


\section{A. Pendahuluan}

Perkembangan tasawuf diwarnai dengan berbagai penyimpangan. Sebagian sufi mencampur adukan ajaran-ajaran agama Islam yang diterima dan menyelewengkan dari ajaran aslinya. Penyimpangan yang dilakukan yaitu mengabaikan syariat, hukum-hukum moral, penghinaan terhadap ilmu pengetahuan, dan menghindarkan diri terhadap rasionalitas dengan menampilkan amalan yang irrasional. Pada abad ke VIII H, lahirlah sebuah konsep pemikiran dari Ibnu Athā'illah yang mengusung nilai-nilai humanisme dalam etika, nilai-nilai humanisme tersebut terpancar dalam konsep etika religius yang merupakan pokok-pokok ajaran tasawuf. ${ }^{1}$ Selain itu, diri yang memiliki etika religius (self religius) akan dimunculkan dalam bentuk akhlaqul karimah atau budi pekerti yang baik, untuk kemudian menjadi kualitas yang ideal dalam diri seseorang. ${ }^{2}$ Konsep etika Ibnu Athā'illah sangat selaras dengan tujuan diciptkannya manusia, dimana konsep etika ini membentuk manusia yang mempunyai jiwa sosial terhadap makhluk hidup (hablu min al-nas) dan kepada Tuhan-nya (hablu min Allah) terjalin bersama.

Tulisan ini akan menghadirkan perspektif baru tentang teori humanisme yang menjadi landasan etika religius perspekirif Ibnu Athā'illah Al-Sakandarī. Teori humanisme pada dasarnya merupakan teori yang dilontarkan oleh Abraham Maslow. Penelitian tentang etika religius perspektif Ibnu Athā'illah pun telah diteliti oleh beberapa peneliti, yakni penelitian yang dilakukan oleh Fermadi, dalam penelitiannya humanisme sebagai dasar pembentukan etika religius. Akan tetapi tulisan tersebut hanya fokus pada pembahasan tentang pandangan Ibnu Athā'illah mengenai makrifat dan belum menyentuh aspek konsep etika religius perspektif Ibnu Athā'illah itu sendiri. Penelitian tersebut pun tidak jauh berbeda dengan penelitian yang dilakukan oleh Moh. Isom Udin dimana ia menilisik lebih mendalam tentang konsep makrifat dari Ibnu Athā'illah. ${ }^{3}$ Sedangkan penelitian yang dilakukan Abdullah Safik justru menitikberatkan pada pemikiran Ibnu Athā'illah tentang tasawuf. ${ }^{4}$ Adapun penelitian yang dilakukan oleh Ishari Nurhafid yang mencoba keluar dari pemikiran peneliti sebelumnya, dengan mengkaji kitab al-Hikam Ibnu Athā'illah kemudian menelisik tentang pendidikan karakter yang ada dalam kitab tersebut. ${ }^{5}$

Membandingkan berbagai penelitian di atas maka penelitian ini, bertujuan mengkaji tentang teori humanisme sebagai dasar etika religius perspektif Ibnu Athā'illah Al-Sakandarī. Tulisan ini akan membedah empat permasalahan pokok yang kemudian akan dibahas dalam penelitian ini yakni: 1) Bagaimana deskripsi tentang biografi Ibnu Athā'illah Al-Sakandarī? 2) Bagaimana ruang lingkup teori humanisme sebagai landasan dari etika religius Ibnu Athā'illah Al-Sakandarī? 3) Bagaimana konstruksi etika religius perspektif Ibnu Athā'illah Al-Sakandarī? 4) Mengapa teori humanisme sebagai landasan etika religius Ibnu Athā'illah Al-Sakandarī memiliki kontribusi di era sekarang terutama terhadap persoalan karakter?

Penulis berargumen bahwasannya teori humanisme yang menjadi landasan dari etika religius Ibnu Athā'illah, memiliki relevansi positif terhadap persoalan yang sedang dihadapi oleh manusia terutama terkait dengan persoalan krisis karakter yang disebabkan oleh krisis

${ }^{1}$ Bayu Fermadi, "Humanisme Sebagai Dasar Pembentukan Etika Relegius; Dalam Perspektif Ibnu Athā'illah Al-Sakandarī,” Jurnal Islam Nusantara 2, no. 01 (2018): 72-87.

${ }^{2}$ Retno Hanggarani Ninin, "Diri Religius: Suatu Perspektif Psikologi Terhadap Kepribadian Akhlaqul Karimah," Psikis : Jurnal Psikologi Islami 5, no. 1 (2019): 1-12, https://doi.org/10.19109/Psikis.v5i1.2041.

${ }^{3}$ Moh. Isom Mudin, “Konsep Makrifat: Ibnu'Ata'Illah Al-Sakandari,” Jurnal Kalimah 14, no. 2 (2016): $155-72$.

${ }^{4}$ Abduloh Safik, "Distingsi Pemikiran Tasawuf Ibn'Ata'Illah Al-Sakandari," Jurnal Kontemplasi 4, no. 2 (2016): 217-30.

${ }^{5}$ Nurhafid Ishari, "Pendidikan Karakter dalam Kitab Al-Hikam Athā'illah Karya Syeikh Ibnu Athā'illah As-Sakandarī,” Jurnal Pendidikan Islam: Tarbiyatuna 10, no. 1 (2017): 66-79. 
moral. Abudin Nata menyatakan bahwa krisis karakter disebabkan oleh longgarnya pegangan terhadap agama sehingga hilangnya kontrol serta derasnya arus budaya materialistis, hedonistik, dan sekularistik. ${ }^{6}$ Penelitian ini menggunakan metode library research yaitu telaah yang dilaksanakan untuk memecahkan suatu masalah yang pada dasarnya, bertumpu pada penelaahan kritis dan mendalam terhadap bahan-bahan pustaka yang relevan, dengan teori humanisme sebagai dasar etika religius dalam perspektif Ibnu Athā'illah Al-Sakandarī. Penelitian library research ini juga akan dipadukan dengan pendekatan filosofis yaitu pendekatan yang memberikan perangkat-perangkat berpikir tentang sesuatu untuk menguji ide-ide atau ingin mengetahui alur pemikiran berjalan. Dalam hal ini yang dimaksudkan adalah berusaha untuk mendalami, mengkaji dan menganalisis pemikiran Ibnu Athā'illah AlSakandarī tentang teori humanisme sebagai dasar etika religius.

Sumber data dalam penelitian ini, berbentuk sumber primer dan sekunder. Adapun sumber primernya adalah kitab yang ditulis oleh Ibnu Athā'illah Al-Sakandarī yang berjudul Lataif al-Minan. Sedangkan sumber sekundernya adalah artikel-artikel yang mengkaji tentang Ibnu Athā'illah Al-Sakandarī seperti yang tulis oleh Abduloh Safik tentang pemikiran tasawuf Ibnu Athā'illah Al-Sakandarī, Nurhafid Ishari tentang pendidikan karakter dalam kitab alHikam, dan Moh Isom Mudin tentang Konsep makrifat Ibnu Athā'illah Al-Sakandarī. Selanjutnya, teknik pengumpulan data dalam penelitian ini dilakukan dengan teknik dokumentasi yakni dengan cara mencari kitab-kitab karangan Ibnu Athā'illah Al-Sakandarī serta artikel-artikel yang mengkaji tentang Ibnu Athā'illah Al-Sakandarī kemudian dianalisis dengan metode deskriptif-analitik.

\section{B. Pembahasan}

\section{B1. Biografi Ibnu Athā'illah Al-Sakandarī}

Ibnu Athā'illah Al-Sakandarī memiliki nama lengkap Ahmad bin Muhammad bin Abd al-Karim bin Athā'illah al-Sakandari al-Maliki al-Syadzili, bergelar 'Ṣāhīb al-Hikam', 'Tāj al-Dīn, 'Tarjuman al- 'Árifin'. Ia Lahir di Mesir sekitar tahun $657 \mathrm{H}$ atau $1259 \mathrm{M}$ dan wafat pada Jumadil Akhir $709 \mathrm{H}$ atau 1310 M, ${ }^{7}$ serta dimakamkan di al-Qurrafah al-Kubra. ${ }^{8}$ Beliau hidup pada masa kedua abad ketujuh dan memasuki awal abad kedelapan Hijriyah. Keluarga Ibnu Athā'illāh adalah keluarga yang terdidik dalam lingkungan agama. Kakek dari jalur nasab ayahnya adalah seorang ulama fikih pada masanya, sekaligus sebagai seorang pengajar dan penasihat kelompok ahli tasawuf. Pada masa remaja Ibnu Athā illah telah belajar tingkat tinggi pada salah satu kota ilmu di semenanjung Mesir yaitu kota Iskandariah. Kota Iskandariah banyak dihuni para ulama dalam bidang ushul, fikih, hadits, dan ilmu-ilmu bahasa Arab. Selain itu, kota Iskandariah juga dihuni oleh tokoh-tokoh tasawuf dan para awliyah' al-Sāliḥ̄nn. ${ }^{9}$ Pemikiran Ibnu Athā 'illah dipengaruhi oleh kondisi sosial masyarakat dan keagamaan di mana ia hidup. Masyarakat pada waktu itu terbagi ke dalam beberapa strata sosial; pemerintah, para intelektual, serta masyarakat awam. ${ }^{10}$ Ibnu Athā 'illah menjadi bagian dari para intelektual serta berperan aktif terhadap pemerintah dalam memberikan nasihat dan kritik yang membangun. ${ }^{11}$ Pada waktu itu, Mazhab Ahlusunnah menjadi mazhab resmi di Mesir, dalam masalah ushul mengikuti mazhab al-Asy'ari dan dalam masalah furū' mengikuti

${ }^{6}$ Abudin Nata, Manajemen Pendidikan Mengatasi Kelemahan Pendidikan Islam di Indonesia. (Jakarta: Kencana, 2012), hlm 222.

${ }^{7}$ Mudin, "Konsep Makrifat: Ibnu'Ata'Illah Al-Sakandari."

${ }^{8}$ Safik, "Distingsi Pemikiran Tasawuf Ibn'Ata'Illah Al-Sakandari."

${ }^{9}$ EL-TeNU., Ziarah Makam Auliya'; Menilisik Lebih Jauh Kehidupan Para Auliya' Mesir (Kairo: LTNU Mesir Press, 2006), hlm 185.

${ }^{10}$ Safik, "Distingsi Pemikiran Tasawuf Ibn'Ata'Illah Al-Sakandari."

${ }^{11}$ Ibnu Athaillah Al-Sakandari, Lataif al-Minan: Edited by Abd Halim Mahmud, 3th edition (Mesir: Dar al-Ma'rif, 2006), hlm. 175. 
paradigma ke-empat mazhab. Maka tidak heran terdapat berbagai macam tarekat sufi, di antaranya al-Rifa'iyah, al-Badawiyyah, al-Qadiriyyah, al-Syadziliyyah. Kondisi sosial dan keagamaan seperti inilah yang mempengaruhi besar dalam pembentukan karakter pemikiran Ibnu Athā illah.

Ibnu Athā'illah meninggalkan sekitar 24 karya intelektual. Salah satu karyanya yang sangat terkenal yaitu Al-Hikam yang merupakan 'Magnum Opus' sekaligus mewakili mazhab tasawuf beliau. Beberapa karyanya yang lain, yang masih bisa ditemukan adalah al-Munājāh al- 'Ațāiyyah, Wașiyyah li Lațāif al-Minan, Tāj al- 'Arūs al-Hāwōi li Tahdzīb al-Nufūs, alQaṣd al-Mujarrad fì Makrifat al-Ism al-Mufrad, Miftāh al-Falāh wa Miṣbāh al-Arwāh, 'Unwān al-Tawfiq fì Ādāb al-Trīq. Sebagian besar karya Ibnu Athā'illah berbentuk 'risālah' yaitu uraian singkat dan padat. ${ }^{12}$

\section{B2. Teori Humanisme sebagai Landasan Etika Religius}

Teori humanisme dipahami sebagai teori yang menekankan pada martabat, peran dan kemampuan manusia, teori ini dimaknai sebagai bentuk gerakan dengan tujuan mempromosikan harkat dan martabat manusia, serta sebagai sebuah pemikiran etis, nilai-nilai kemanusiaan yang sangat dijunjung tinggi. ${ }^{13}$ Asumsi dasar teori humanisme adalah menganggap manusia memiliki potensi-potensi yang baik, minimal lebih banyak baiknya dari pada buruknya. ${ }^{14}$ Dalam teori ini, manusia dituntut untuk bermartabat luhur, mampu mengembangkan diri untuk memenuhi kehidupannya, serta dapat membedakan antara hal yang baik juga hal yang buruk sehingga ia bertanggung jawab atas perilaku dan pilihan dihidupnya.

Kata Humanisme memiliki banyak pengertian, dilihat dari sisi kebahasaan, istilah humanisme berasal dari kata latin humanus berarti sifat manusiawi atau sesuai dengan kodrat manusia. Adapun secara terminologi, humanisme berarti martabat dan nilai dari setiap manusia, serta upaya untuk meningkatkan kemampuan-kemampuan alamiah yang dimilikinya baik fisik maupun non fisik secara maksimal. ${ }^{15}$ Dalam psikologi, humanisme juga dikenal dengan sebutan humanistik. Pada paruh pertama abad kedua puluh, psikologi humanistik terlahir dikarenakan beberapa psikolog seperti Gardon Allport, Carl Rogers, Abraham Maslow dan beberapa tokoh-tokoh lainnya yang mulai tidak betah terhadap psikologi bahavioristik. Mereka melihat behavioristik hanya menghasilkan gambaran tentang hakikat manusia hanya dari satu dimensi, padahal manusia terdiri atas respon-respon luar yang dikontrol sepenuhnya oleh lingkungan eksternal serta manusia juga tumbuh, berpikir, merasa, bermimpi, mencipta dan melakukan aktivitas-aktivitas lain yang semakin menambah pengalaman kemanusiaannya. Kaum behavioristik banyak sekali mengabaikan aspek kehidupan yang membuat manusia unik dan bermartabat. Sedangkan kaum humanistik berpendapat bahwa psikologi mestinya mengarahkan diri pada pengalaman kemanusiaan seutuhnya dan tidak hanya meneliti aspek-aspek yang bisa diukur di bawah lingkungan yang terkontrol. $^{16}$

Zainal Abidin memberikan penjelasan tentang latar belakang pemahaman humanisme. Menurutnya istilah humanisme dapat dipahami dengan meninjaunya dari dua sisi yaitu sisi historis dan sisi aliran filsafat. Dari sisi historis, humanisme adalah gerakan intelektual dan

\footnotetext{
${ }^{12}$ Mudin, "Konsep Makrifat: Ibnu'Ata'Illah Al-Sakandari."

${ }^{13}$ Fermadi, "Humanisme Sebagai Dasar Pembentukan Etika Relegius; Dalam Perspektif Ibnu Athā'illah Al-Sakandarī."

${ }^{14}$ In Tri Rahayu, Psikoterapi Perspektif Islam \& Psikologi Kontemporer (Malang: UIN-Malang Press, 2009), hlm.71.

${ }^{15}$ A. Mangunhardjana, Isme-Isme dari A Sampai Z (Yogyakarta: Kanisius, 1997), hlm. 93.

16 Masbur, "Internalisasi Nilai-Nilai Pendidikan Perspektif Abraham Maslow (1908-1970); Analisis Filosofis," Jurnal Ilmiah Edukasi 1, no. 1 (2015): 29-47.
} 
kesusastraan yang awalnya muncul di Italia sekitar abad ke 14 M. Gerakan ini, dikatakan sebagai roda penggerak kebudayaan modern khususnya di Eropa. Sementara dari sisi aliran filsafat, humanisme diartikan sebagai paham yang menjunjung tinggi nilai dan martabat manusia sedemikian rupa sehingga manusia menempati posisi yang sangat tinggi, sentral dan penting, baik dalam perenungan teoritis filsafat maupun dalam praktis kehidupan seharihari. ${ }^{17}$ Hal ini sejalan dengan ungkapan Lorens Bagus dalam bukunya bahwa humanisme sebagai sebuah filsafat, yaitu: memandang individu sebagai nilai tertinggi serta humanisme ditujukan untuk membina perkembangan kreatif dan moral individu, dengan cara bermakna dan rasional tanpa merujuk pada konsep-konsep adikodrati. Ungkapan Lorens Bagus tidak jauh berbeda dengan Ali Syari'ati yang juga mengartikan humanisme sebagai aliran filsafat yang menyatakan bahwa tujuan pokok yang dimilikinya adalah untuk keselamatan dan kesempurnaan. $^{18}$

Peran manusia dalam hal ini merupakan bentuk dari tanggung jawab terhadap dirinya, sehingga ia dapat mempunyai arti dan nilai dalam menjalani hidup ini. Selain peran yang berujung pada tanggung jawab, teori humanisme yang pada dasarnya menjunjung tinggi nilainilai kemanusiaan menjadikan etika atau moralitas sebagai salah satu nilai-nilai kemanusiaan. ${ }^{19}$ Kebahagiaan dan kemajuan di berbagai bidang seperti ekonomi, pendidikan serta budaya, hingga kebebasan yang terlepas dari perbedaan suku, bangsa atau agama merupakan tujuan tertinggi dari sebuah nilai etika dalam hubungan antar manusia, serta pengalaman duniawi.

Kalangan humanisme religius meyakini bahwa manusia memiliki sifat dasar yang telah dianugerahkan Tuhan untuk mengembangkan segala potensinya, karena dalam diri manusia terdapat dua naluri, yakni naluri alamiah dan naluri ketuhanan. Keduanya saling mengisi dan tidak bertentangan. ${ }^{20}$ Sehingga dengan naluri itu manusia pada hakikatnya mempunyai pandangan untuk mendekatkan diri kepada Tuhannya dengan berbagai cara seperti uzlah, zuhud, dan riadhoh al-nafs yang merupakan cara untuk mendapatkan kebahagiaan dari segi jiwa. Ketiga cara tersebut tentunya tidak terlepas dari tasawuf, sehingga beberapa orang pun berpendapat bahwa kebahagiaan yang sesungguhnya adalah ketika manusia telah mencapai makrifat Tuhan. ${ }^{21}$ Pemikiran kaum muslimin mengiringi perkembangan tasawuf yang begitu cepat. Banyaknya pemikiran yang berasal dari tasawuf tentang cara untuk mencapai hakikat kebahagiaan, seperti pemikiran Suhrawardi Al- Maqtul dengan teori Isyraqiyah (pancarannya), kemudian dengan Ibnu Arabi dengan Wahdatul Wujud-nya, Ibnu Sabi'in dengan teori Ittihad-nya, dimana ketiga pemikiran ini mengartikan tujuan tertinggi dari nilai etika atau akhlak sebagai jalan menuju Tuhan-nya. Namun di tengah banyaknya pemikiran yang menjadikan Tuhan sebagai tujuan kebahagiaan, manusia pun akhirnya berfokus pada tujuan akhir saja, dan lupa terhadap proses menuju Tuhannya yaitu hubungan mereka antar sesama serta memperoleh pengalaman duniawinya.

Secara universal, etika sebagai ajaran agama Islam juga merupakan sebuah refleksi manusia tentang apa yang dikerjakannya untuk menjadi seorang manusia sempurna. Etika menjadi jalan bagi manusia untuk mengenali perbuatan yang baik dan buruk, salah ataupun

${ }^{17}$ Zainal Abidin, Filsafat Manusia (Bandung: Rosdakarya, 2001), hlm. 39.

${ }^{18}$ Ali Syari'ati, Humanisme Antara Islam dan Barat (Jakarta: Pustaka Hidayah, 1992), hlm. 39.

${ }^{19}$ Bayu Fermadi, "Konsep Etika Religius Ibnu Athā'illah Al-Sakandarī,” Asy-Syari'ah : Jurnal Hukum Islam 4, no. 2 (2018): 127-50, https://doi.org/10.36835/assyariah.v4i2.105.

${ }^{20}$ Husna Amin, "Aktualisasi Humanisme Religius Menuju Humanisme Spiritual Dalam Bingkai Filsafat Agama," SUBSTANTIA 15, no. 1 (15 April 2013): 66-80, https://doi.org/10.22373/subtantia.v15i1.4885, hlm. 66.

${ }^{21}$ H. Baharun, "Pemikiran Pendidikan Perspektif Filsuf Muslim (Kajian Kritis terhadap Pemikiran Muhammad Abduh dan Muhammad Iqbal). Jurnal At-Turas, 3(1).," Jurnal At-Turats 3, no. 1 (2016): 71-87, hlm. 81 . 
benar. Sementara, konsep etika dalam tinjauan filsafat dapat dimaknai sebagai pola kehidupan yang baik dan menginginkan hal-hal yang baik dalam hidup. ${ }^{22}$ Adapun etika dan agama merupakan sesuatu yang berkaitan dalam diri manusia. Sehingga dalam Islam etika meletakkan teks-teks suci sebagai sumber kebenarannya. Kebenaran yang bersumber dari keagamaan tidak akan kehilangan substansi makna di dalamnya. ${ }^{23}$

K. Bertens menjelaskan bahwa etika berasal dari bahasa Yunani Kuno yaitu ethos yang merupakan kata tunggal yang memiliki banyak makna, seperti; kebiasaan, adat, akhlak, watak, perasaan, sikap dan cara berpikir. ${ }^{24}$ Etika dipahami sebagai ilmu tentang apa yang biasa dilakukan atau ilmu tentang adat kebiasaan. ${ }^{25}$ Dalam perkembangannya, etika sering sekali disamakan dengan moral akan tetapi Sidi Ghazelba menjelaskan perbedaan antara moral dan etika. Menurutnya, moral bersifat praktik sedangkan etika bersifat teori, sehingga apa yang dilakukan oleh manusia tercermin dari perilaku moral manusia itu sendiri. ${ }^{26}$ Sedangkan menurut al-Ghazali, moral atau etika bukan hanya sekedar perbuatan, bukan pula sekedar kemampuan berbuat, juga bukan pengetahuan atau teori saja. Akan tetapi lebih dari itu, sebab moral dan etika adalah upaya menggabungkan dirinya dengan situasi jiwa yang siap memunculkan perbuatan-perbuatan, dan situasi itu harus melekat sedemikian rupa sehingga perbuatan yang muncul darinya tidak bersifat sesaat melainkan menjadi kebiasaan dalam kehidupan sehari-hari. ${ }^{27}$

Etika sebagai bagian dari filsafat praktis (hikmah amaliyah) juga sering dipadankan dengan kata akhlak. Murtadha Muthahari menjelaskan, pada umumnya akhlak didefinisikan sebagai ilmu tentang cara hidup atau bagaimana seharusnya hidup dengan baik. Akhlak mempunyai peranan penting dalam menentukan kehidupan dan pergaulan. Kejatuhan sebuah negara bukan disebabkan karena krisis intelektual, akan tetapi karena krisis akhlak. ${ }^{28}$ Muhammad Taqi Misbah berpendapat bahwa akhlak sebagai sifat yang melekat pada jiwa manusia. Sifat itu menjadi sumber kemunculan perilaku yang khas, tanpa melalui pertimbangan pikiran. Karena itu, akhlak merupakan karakter yang melekat kuat pada masing-masing jiwa manusia yang dengan mudah melahirkan tindakan tanpa melalui tindakan, seperti marahnya seorang penyabar. ${ }^{29}$

Selanjutnya, berbicara tentang etika dalam Islam, tentunya tidak lepas dari dasar yang mempengaruhi etika itu sendiri, yaitu agama Islam yang menjadi sumber dalam kajian ini. Karena itu, etika dalam Islam dapat diidentikkan dengan ilmu akhlak yaitu ilmu tentang keutamaan-keutamaan dan bagaimana cara mendapatkannya agar manusia berhias denganNya. Konsep etika dalam Islam salah satunya etika religius. Perbedaan mencolok yang dimiliki etika religius yaitu berakar dalam al-Qur'an dan Sunnah, dimana pada satu sisi cenderung melepaskan kepelikan dialektika atau metodologi dan memusatkan pada usaha untuk mengeluarkan spirit moralitas Islam. Selain berakar dari al-Qur'an dan Sunnah, etika religius mempunyai pembahasan yang berada pada ranah teologis dan sufistik. Unsur utama

\footnotetext{
${ }^{22}$ Fermadi, "Konsep Etika Religius Ibnu Athā'illah Al-Sakandarī.,,hlm. 79.

${ }^{23}$ Wiji Suwarno, Etika Islam dan Produktivitas Menulis Pustakawan pada Perguruan Tinggi Keagamaan Islam Negeri, Disertasi (Yogyakarta: UIN Sunan Kalijaga Yogyakarta, 2019), hlm.8.

${ }^{24}$ K. Bertens, Etika (Jakarta: Gramedia Pustaka Jaya, 2004), hlm 4.

${ }^{25} \mathrm{Ibid}$.

${ }^{26}$ Abd Haris, Etika Hamka (Yogyakarta: Lkis, 2010), hlm. 34.

${ }^{27}$ H. Baharun, "Total Moral Quality: A New Approach for Character Education in Pesantren," Jurnal Ulumuna 21, no. 1 (2017): 57-80.

${ }^{28} \mathrm{Abu}$ Muhammad Iqbal, Pemikiran Pendidikan Islam "Gagasan-Gagasan besar para ilmuan Muslim," 1 ed. (Yogyakarta: Pustaka Pelajar, 2015), hlm 443.

${ }^{29}$ M.T Misbah Yaqzdi, Meniru Tuhan: Antara Yang Terjadi dan yang Mesti Terjadi, terj. Ammar Fauzi Heriyadi (Jakarta: al-Huda, 2006), hlm. 191.
} 
etika pun terkonsentrasi pada dunia manusia yang lebih kompleks dan berciri Islam. ${ }^{30}$

\section{B3. Konstruksi Etika Religius Perspektif Ibnu Athā'illah Al-Sakandarī}

\section{Internalisasi Nilai-Nilai Humanisme dalam Pemikiran Ibnu Athai'llah}

Pada masa perkembangan ilmu tasawuf terjadi gerakan persaudaraan yang mengekspresikan dan mengkristalkan persaingan suku dalam ritual dan upacara. Dengan demikian nalar atau pemikiran yang berkembang berjuang untuk melawan nalar saingannya, sehingga menumbuhkan pengakuan terhadap pemikiran tersebut, begitu juga pemikiran Ibnu Athā'illah yang berjuang terhadap pemikiran abad sebelumnya sehingga memunculkan transendensi terhadap pemikiran Ibnu Athā'illah. Tasawuf pada dasarnya adalah ajaran ruhaniyah (spiritual), penerapan ajaran mistik untuk memahami Islam tentu membawa perubahan besar. Aspek-aspek kerohanian Islam yang mereka tekankan dan dikembangkan dengan penafsiran dan pemahaman dari sudut ajaran tasawuf. Tasawuf sebagai suatu ajaran mistik memang berwatak eskapisme (kehendak atau kecenderungan menghindar dari kenyataan dengan mencari hiburan dan ketenteraman di dalam khayal atau situasi rekaan), karena penguasaan ilmu gaib dan makrifat pada zat Tuhan adalah kebesaran yang segalagalanya. Maka mereka berpendapat bahwa apa saja selain Allah adalah hijab atau tabir penutup, yang memburamkan serta mengotori hati manusia. ${ }^{31}$

Ajaran tasawuf yang dikembangkan oleh Ibnu Athā'illah merupakan ajaran tasawuf yang dapat bertahan sampai saat ini, disebabkan ajaran tasawuf yang mempunyai nilai universal dan juga tidak keluar dari ajaran yang baku yaitu al-Qur'ān dan Sunnah. Pemikiran tersebut tidak serta merta disepakati oleh pemikir lainya sehingga masih terbukanya kritikan atas pemikiran, sehingga terbukanya berbagai temuan yang tidak terpikirkan oleh manusia. Menurut Arkoun pemikir Islam tidak menyadari bahwa bukan hanya pemahaman dan penafsiran yang ditetapkan, melainkan pemahaman dan penafsiran lain seharusnya ikut ditetapkan, namun sayangnya hal tersebut justru disingkirkan. Dengan demikian menimbulkan pembekuan dan penutupan pemikiran Islam, serta menimbulkan ketidakmampuan pemikir Islam dalam menjawab masalah umat Islam dewasa ini. ${ }^{32}$

Berdasarkan pemikiran Ibnu Athā'illah yang tertuang dalam ajaran tasawuf, dapat dikatakan bahwa masih terbukanya kritikan terhadap pemikiran tersebut, bukan hanya sebatas pada cara pandang tetapi juga pada ritus tasawuf, ada beberapa hal yang merupakan kritik atas pemikiran Ibnu Athā'illah, yaitu dalam ajaran tasawuf Ibnu Athā'illah lebih terpengaruh pada pemikiran tasawuf abad ke V H salah satunya adalah al-Ghazālī, keterpengaruhan tersebut muncul disebabkan kesamaan faktor sosial yaitu munculnya penyelewengan-penyelewengan terhadap ajaran tasawuf, sehingga perlunya purifikasi atas ajaran tersebut.

Tasawuf yang dipandang sebagai penghalang kemajuan Islam, memunculkan gerakan purifikasi yang digagas oleh Ibnu Taimiyah. Gerakan ini muncul sebagai gerakan pengembalian ajaran tasawuf yang keluar dari ajaran Islam, kembali ke jalan yang benar. Menurut Kung, ${ }^{33}$ dalam ajaran tasawuf Ibnu Athā'illah pun pada akhirnya mengadopsi humanisme menjadi dasar ajaran tasawufnya. Konsep tersebut mempengaruhi manusia dalam bertindak ataupun bertingkah laku. Dengan kata lain, humanisme telah menjadi ciri dari pemikiran dan etika religiusnya, juga merupakan antitesis dari ajaran tasawuf yang berkembang di abad sebelumnya.

\footnotetext{
${ }^{30}$ Haris, Etika Hamka.

${ }^{31}$ Simuh, Tasawwuf dan Perkembangannya dalam Islam (Jakarta: Raja Grafindo Persada, 1996), hlm 159.

${ }^{32}$ A. Fauzi, "Model Manajemen Pendidikan Islam; Telaah atas 'Pemikiran' dan 'Tindakan Sosial,", Journal At-Ta’lim INZAH Zainul Hasan Genggong Probolinggo 2, no. 2 (2017): 16.

${ }^{33}$ Ibid.
} 
Nilai-nilai etika Ibnu Athā'illah berada pada pandangan yang berada di tengah-tengah atau wasath. Berbasis pada al-Qur'ān dan Sunnah yang kemudian menjadikan ajaran ini dapat diterima di berbagai kalangan, ilmuwan, pekerja dan sebagainya, selain itu dengan nilai humanisme, harmonisasi dalam masyarakat terbentuk sehingga umat Islam tidak berada pada perdebatan dalam menjalankan kodrat sebagai manusia. Ibnu Athā'illah menganjurkan manusia untuk mencapai tingkat tertinggi yaitu makrifat, kemudian menganjurkan juga bagi pengikut sufi untuk menuntut ilmu dan pengembangan pada akal. Dengan kata lain, Ibnu Athā'illah mendorong manusia untuk berkembang sesuai dengan keadaan zaman dengan tidak meninggalkan kepatuhan kepada Tuhan. Sehingga menjadi manusia dengan pribadi yang baik, tidak hanya terbatas pada persoalan penyerahan total pada ketetapan Allah Swt., akan tetapi bagaimana manusia mampu terus cemerlang dengan selalu berpikir yang positif dengan akalnya, sehingga setiap kesusahan dan ujian yang berlaku tidak mengakibatkan resah maupun putus asa, serta kesenangan dan anugerah tidak menyebabkan lupa diri dan lalai. ${ }^{34}$

Ibnu Athā'illah menjadi tokoh sufi yang tidak menolak kemodernisasian, atau menghambat ilmu pengetahuan, sebab Ibnu Athā'illah menganjurkan manusia untuk bekerja, belajar, berilmu, bersosial terhadap sesama dan tidak menganjurkan yang sebaliknya yaitu mengasingkan diri, jauh dari hiruk pikuk kehidupan manusia, karena hal tersebut menyalahi ketentuan Tuhan yang telah menjadikan manusia sebagai khalifah di bumi. ${ }^{35}$ Ibnu Athā'illah memandang bahwa pengembalian ajaran kepada al-Qur'an dan Sunnah merupakan kewajiban bagi umat Islam, karena keduanya merupakan dasar tiang penyangga dari agama Islam, tetapi tidak secara parsial semuanya dikembalikan kepada al-Qur'an dan Sunnah, ada ruang ijtihad yang masih terbuka lebar. Ruang ijtihad ini sebagai pintu berkembangnya pemikiran umat Islam. Ijtihad ini juga yang digunakan Ibnu Athā'illah untuk memilah tasawufnya hingga sesuai dengan keadaan manusia dan berkembang hingga saat ini. Dengan kata lain, Ibnu Athā'illah mencoba mencari jalan keluar dari polemik pemikiran yang terjadi saat itu, untuk kemudian menjawab permasalahan-permasalahan umat Islam.

Saat ini pemikiran Ibnu Athā'illah dapat menjadi solusi kekeringan hati dan pemikiran yang terjadi pada umat Islam, dengan keseimbangan hubungan antara Tuhan dan manusia sebagai jawaban atas keresahan umat Islam. Aktualisasi nilai-nilai humanisme dalam kehidupan sangat perlu untuk dikedepankan pada era globalisasi pada saat ini sebab sikap yang terkandung dalam humanisme pandangan Islam berarti sikap yang mengedepankan sisi kemanusiaan yang berlaku adil dan hidup damai di tengah perbedaan. ${ }^{36}$

\section{Makrifat: Refleksi Nilai-nilai Humanisme sebagai Konstruksi Etika Religius}

Abu al-Abbas al-Mursi memprediksi pribadi Ibnu Atha'illah sebagai orang yang bijak menjadi tokoh sufi yang bijak pula, ${ }^{37}$ ia mempunyai konsep yang sama dengan Ibnu Taimiyah dalam hal tasawuf, yaitu pemurnian ajaran tasawuf dan mengembalikan tasawuf pada ajaran yang menganut kepada al-Qur'ān dan Sunnah. Karena itu, manusia dituntut untuk mempunyai karakter yang baik, baik dimata manusia ataupun dimata Tuhan. Dengan demikian manusia dapat dikatakan baik ketika berperilaku sesuai dengan kodrat manusia. Dalam hubungan antar manusia Ibnu Athā'illah menekankan bahwa manusia harus menjalin hubungan antar

\footnotetext{
${ }^{34}$ Syed Hadzrullathfi Syed Omar dan Nurul Arifah Musa, "Pembentukan Ummah Wasatiyyah Menerusi Terapi Tauhid Al-Hikam Shaykh Ibn Ataillah,” Jurnal Islam dan Masyarakat Kontemporari 16, no. 1 (31 Januari 2018): 11-21, hlm. 18.

${ }^{35}$ A. Fauzi, "Transkulturasi Social Capital Pesantren; Sebagai Paradigma Pendidikan Islam Moderat," 2St Annual Conference For Muslim Scholars, Strengthening The Moderate Vision of Indonesia Islam. Surabaya 2 (2018): 751-765.

${ }^{36}$ Husna Amin, “Aktualisasi Humanisme Religius Menuju Humanisme Spiritual Dalam Bingkai Filsafat Agama", hlm 74.

${ }^{37}$ Al-Sakandari, Lataif al-Minan: Edited by Abd Halim Mahmud.
} 
masyarakat ataupun bersosial, akan tetapi ada kriteria yang dijadikan acuan dalam bermasyarakat.

Apabila dilihat dari sudut pandang Arkoun, pemikiran Ibnu Athā'illah merupakan bentuk dari harmonisasi pemikiran yang ada, disebabkan karena benturan-benturan pemikiran yang berkembang dengan keadaan masyarakat Islam dan teks yang bersumber dari al-Qur'ān dan Hadis. Dengan demikian pemikiran Ibnu Athā'illah seperti penengah diantara para pemikir-pemikir Islam yang berhubungan dengan Tasawuf. Kemudian dalam pandangan etika sebagai jalan menuju kebahagiaan Ibnu Athā'illah menganjurkan kepada para pengikutnya untuk tidak meninggalkan tanggung jawab sebagai manusia dan mempunyai peran terhadap lingkungannya, dalam konteks secara besar dapat disimpulkan bahwa untuk mencapai kebahagiaan tertinggi manusia harus dapat membersihkan diri pada level pertama yaitu pada level kemanusiaan.

Pada level kemanusiaan, manusia selalu diuji pada tataran hubungan sosial atau sesama makhluk hidup. Sabar, jujur, tawakal dan ikhlas sebagai dasar dalam menjalin hubungan antar sesama makhluk hidup. Dengan demikian nilai-nilai humanisme pada manusia dapat tercapai, sehingga manusia dapat menjalankan kehidupannya sebagai manusia normal. Dengan akal manusia dapat membedakan mana yang baik dan mana yang buruk, akal pun yang membedakan manusia dengan binatang. Manusia menggunakan akal untuk mencari kebenaran yang ada di dunia ini. Menurut al-Ghazālī akal berarti makrifat yang merupakan puncak dari segala tingkatan akal, yaitu keinsafan rohani manusia yang menyadari akibat sesuatu, dan yang membawanya kepada keluhuran budi akhlak, serta memimpinya kepada ketuhanan yang setinggi-tingginya. ${ }^{38}$ Kedudukan tinggi yang dimiliki manusia oleh Ibnu Athā'illah diilustrasikan sebagai makhluk mulia yang berada antara dua alam, yakni alam materi dan alam malakut. Sebagaimana yang dituturkan dalam hikmah yang artinya: "Allah menjadikanmu di alam pertengahan antara alam materi dan alam malakut-Nya guna memperkenalkan tingginya kedudukanmu diantara makhluk. Kau adalah mutiara yang tersembunyi dalam kulit ciptaan-Nya". ${ }^{39}$

Menurut Ibnu Athā'illah seseorang yang ingin mendapatkan makrifat bukan berarti dia harus meninggalkan akal dan fokus terhadap Ubudiah, tetapi berpikir merupakan cara manusia dalam berikhtiar hingga mendapatkan kebenaran tentang adanya Tuhan. Ibnu Athā'illah menolak tentang praktik tasawuf yang meninggalkan penggunaan akal, dan fokus terhadap riadhah al-nafs, karena menurutnya beribadah saja tidak cukup tetapi dibarengi dengan tafakur seperti yang telah Allah firmankan dalam Q.S. Al-Imron ayat 190-191. ${ }^{40}$

Dalam pemikiran Islam, keimanan menentukan perbuatan dan keyakinan mengatur perilaku, ${ }^{41}$ perbuatan manusia akan terpancar pada perilaku sehari-hari begitu juga dalam menuntut ilmu. Ibnu Athā'illah berpendapat bahwa ilmu dapat menghantarkan manusia untuk mendapatkan kebahagiaan, Allah berfirman dalam Q.S. al-Mujadalah ayat 11 bahwa Allah akan meninggikan derajat orang yang menuntut ilmu. Oleh karena itu, Ibnu Athā'illah menganjurkan pengikutnya untuk menuntut ilmu, sebab dengan ilmu manusia dapat berkembang sesuai dengan keadaan zaman, kemudian bersama ilmu manusia dapat menemukan Tuhan-nya. Jadi dapat dikatakan bahwa tasawuf bukan sebagai menghambat ilmu pengetahuan, tetapi sebaliknya bahwa tasawuf mendorong manusia untuk mendalami ilmu pengetahuan. Penjabaran-penjabaran di atas merupakan reaksi dari Ibnu Athā'illah dalam

\footnotetext{
${ }^{38}$ Abidin, Filsafat Manusia.

${ }^{39}$ Ghozi Ghozi, "Landasan Ontologis Dan Kualifikasi Makrifat Ibn "Atâ' Allâh al-Sakandarî," TEOSOFI: Jurnal Tasawuf Dan Pemikiran Islam 6, no. 1 (3 Juni 2016): 57-91, hlm 84-5.

${ }^{40}$ A. Fauzi, "Pengembangan Human Relation Perspektif Nilai-nilai al-Qur'an," Jurnal Mutawatir UIN Sunan Ampel Surabaya 1, no. 2 (2015): 168-179.

${ }^{41}$ Fauzi, "Model Manajemen Pendidikan Islam; Telaah atas 'Pemikiran' dan 'Tindakan Sosial.'”
} 
menanggapi pertentangan-pertentangan pemikiran sehingga muncullah tasawuf yang menjadi jalan tengah dari pertentangan pemikiran tersebut yaitu tasawuf yang berdasarkan pada nilai humanisme.

\section{B4. Relevansi Teori Humanisme Etika Religius Ibnu Athā'illah Al-Sakandarī di Era Sekarang}

Belum ditemukan secara gamblang relevansi teori humanisme etika religius dalam pandangan Ibnu Athā'illah. Akan tetapi dari penjelasan pada sub bab sebelumnya, dimana nilai-nilai makrifat merupakan refleksi dari teori humanisme sebagai konstruksi etika religius, peneliti pun melihat bahwa relevansi teori humanisme etika religius Ibnu Athā'illah saat ini, bisa dilihat pada pendidikan karakter di Indonesia.

Corak pemikiran Ibnu Atha'illah yang menyinggung tentang pendidikan karakter lebih menekankan terhadap nilai-nilai Uluhiyah (ketuhanan). Oleh karenanya, hakikat pendidikan karakter Ibnu Atha'illah adalah sebuah proses penanaman nilai yang tujuan akhirnya adalah mendekatkan diri kepada Allah swt. atau menjadi pribadi yang baik disisi-Nya. Dengan kata lain, nilai-nilai yang ditanamkan pada diri seorang pelajar atau diri sendiri adalah nilai-nilai karakter yang berorientasi dalam upaya untuk menjadi pribadi yang sedekat mungkin kepada Allah swt. Jika dilihat secara sekilas, penanaman nilai-nilai tersebut hanyalah nilai agama, tidak mencakup nilai kebangsaan dan sosial kemasyarakatan. Namun, jika dilihat dari sudut konteks atau isi dari penanaman nilai agama dapat dipahami bahwa saat seseorang mampu menanamkan nilai-nilai agama dalam dirinya, maka akan berorientasi terhadap nilai-nilai kebangsaan dan sosial kemasyarakatannya. Hal tersebut, tentunya memberikan pemahaman bahwa hakikat pendidikan karakter Ibnu Atha'illah tentunya tidak jauh berbeda dengan pendidikan karakter nasional yang bertujuan untuk mengembangkan potensi anak didik untuk memiliki kekuatan spiritual keagamaan, pengendalian diri, kepribadian, kecerdasan, akhlak mulia, serta keterampilan yang diperlukan dirinya, masyarakat, bangsa dan negara. ${ }^{42}$ Tujuan tersebut kemudian diperkuat dengan delapan belas nilai utama karakter yang penting untuk diinternalisasikan antara lain: religius, jujur, disiplin, kerja keras, kreatif, rasa ingin tahu, peduli sosial, dan tanggung jawab. ${ }^{43}$

Religius atau nilai spiritual keagamaan menjadi nilai utama karakter yang perlu diinternalisasikan karena berkaitan dengan pandangan pribadi dan perilaku seseorang yang mengekspresikan tujuan hidup dan arti hidup, kesadaran diri, dan segala yang dialami selalu dikaitkan dengan dimensi transendental yaitu Tuhan Yang Maha Esa, yang berimplikasi pada semangat kebangsaan atau hubbul wathan dan cinta sesama. ${ }^{44}$

Selanjutnya, relevansi teori humanisme etika religius Ibnu Athā'illah juga bisa dilihat dari strategi pendidikan karakter. Strategi pendidikan karakter dalam pandangan Ibnu Atha'illah dibagi dalam dua tahapan, yaitu proses penanaman dan penyebaran. Hal itu sangat relevan dengan strategi pendidikan karakter nasional, yaitu intervensi (penanaman pada diri peserta didik), dan habituasi (penanaman melalui lingkungan). Namun dalam hal ini, beliau lebih mengarah terhadap pelaku dalam pendidikan tersebut, artinya pendidikan karakter yang dikehendaki beliau tidak menjelaskan tentang apa yang harus dilakukan oleh seorang guru, namun lebih apa yang harus dilakukan oleh seorang peserta didik sehingga peserta didik mampu mengaktualisasikan segenap kemampuan yang ada pada dirinya.

42"UU no 20 th 2003 tentang SPN.pdf," Google Docs, diakses 28 Oktober 2019, https://drive.google.com/file/d/14rj65yvlU8reSd8m2Po3gZVfstD_cg1X/view?usp=sharing\&usp=embed_facebo ok.

${ }^{43}$ Kementrian Pendidikan Nasional, Pengembangan Pendidikan Budaya dan Karakter Bangsa (Jakarta: Badan Penelitian dan Pengembangan Pusat Kurikulum, 2010), hlm. 9-10.

${ }^{44}$ Maragustam, Filsafat Pendidikan Islam Menuju Pembentukan Karakter (Yogyakarta: Pascasarjana. Fakultas Ilmu Tarbiyah dan Keguruan UIN Sunan Kalijaga, 2018), hlm. 267. 


\section{Penutup}

Berdasarkan permasalahan dan temuan penelitian teori humanisme sebagai dasar etika religius perspektif Ibnu Athā'illah Al-Sakandarī, maka disimpulkan bahwa Ibnu Athā'illah sebagai tokoh sufi yang tidak menolak kemodernisasian, atau menghambat ilmu pengetahuan, melainkan menganjurkan manusia untuk bekerja, belajar, berilmu, bersosial terhadap sesama. Konstruksi etika religius perspektif Ibnu Athā'illah dalam penelitian ini pun terdiri dari internalisasi nilai-nilai humanisme dan makrifat yang menjadi refleksi nilai-nilai humanisme sebagai konstruksi etika religius.

Internalisasi nilai-nilai humanisme dalam pemikiran Ibnu Athā'illah berada pada ajaran tasawuf. Dalam ajaran tasawuf Ibnu Athā'illah, humanisme menjadi dasar ajaran tasawuf. Konsep tersebut mempengaruhi manusia dalam bertindak ataupun bertingkah laku. Dengan kata lain humanisme telah menjadi ciri dari pemikiran dan etika religiusnya, juga merupakan antitesis dari ajaran tasawuf yang berkembang di abad sebelumnya. Selain itu, makrifat adalah Tujuan tertinggi manusia dalam mencari kebahagiaan juga mampu membuat manusia merasa damai dan tenteram disebabkan telah mengetahui sedikit tentang Tuhannya. Oleh karena itu, manusia pun dituntut untuk mempunyai karakter yang baik, baik dimata manusia ataupun dimata Tuhan. Manusia dapat dikatakan baik pun, ketika berperilaku sesuai dengan kodrat manusia. Dalam hubungan antar manusia Ibnu Athā'illah menekankan bahwa manusia harus menjalin hubungan antar masyarakat ataupun bersosial, akan tetapi ada kriteria yang dijadikan acuan dalam bermasyarakat. Berlandaskan hal tersebut, dapat diketahui bahwa makrifat menjadi refleksi nilai-nilai humanisme sebagai konstruksi etika religius.

Selanjutnya, keterbatasan penelitian teori humanisme sebagai dasar etika religius perspektif Ibnu Athā'illah Al-Sakandarī yaitu belum ditemukannya secara gamblang relevansi teori humanisme etika religius dalam pandangan Ibnu Athā'illah, sehingga pada penelitian selanjutnya diharapkan agar melakukan penelitian relevansi teori humanisme etika religius Athā'illah Al-Sakandarī di era sekarang.

\section{DAFTAR PUSTAKA}

Abidin, Zainal. Filsafat Manusia. Bandung: Rosdakarya, 2001.

Al-Sakandari, Ibnu Athaillah. Lataif al-Minan: Edited by Abd Halim Mahmud. 3th edition. Mesir: Dar al-Ma'rif, 2006.

Amin, Husna. "Aktualisasi Humanisme Religius Menuju Humanisme Spiritual Dalam Bingkai Filsafat Agama." SUBSTANTIA 15, no. 1 (15 April 2013): 66-80. https://doi.org/10.22373/subtantia.v15i1.4885.

Baharun, H. "Pemikiran Pendidikan Perspektif Filsuf Muslim (Kajian Kritis terhadap Pemikiran Muhammad Abduh dan Muhammad Iqbal). Jurnal At-Turas, 3(1).” Jurnal At-Turats 3, no. 1 (2016): 71-87.

- "Total Moral Quality: A New Approach for Character Education in Pesantren." Jurnal Ulumuna 21, no. 1 (2017): 57-80.

Bertens, K. Etika. Jakarta: Gramedia Pustaka Jaya, 2004.

EL-TeNU. Ziarah Makam Auliya'; Menilisik Lebih Jauh Kehidupan Para Auliya' Mesir. Kairo: LTNU Mesir Press, 2006.

Fauzi, A. "Model Manajemen Pendidikan Islam; Telaah atas 'Pemikiran' dan 'Tindakan Sosial."” Journal At-Ta'lim INZAH Zainul Hasan Genggong Probolinggo 2, no. 2 (2017): 16.

"Pengembangan Human Relation Perspektif Nilai-nilai al-Qur'an." Jurnal Mutawatir UIN Sunan Ampel Surabaya 1, no. 2 (2015): 168-179. 
. "Transkulturasi Social Capital Pesantren; Sebagai Paradigma Pendidikan Islam Moderat." 2St Annual Conference For Muslim Scholars, Strengthening The Moderate Vision of Indonesia Islam. Surabaya 2 (2018): 751-765.

Fermadi, Bayu. "Humanisme Sebagai Dasar Pembentukan Etika Religius; Dalam Perspektif Ibnu Athā'illah Al-Sakandarī.” Jurnal Islam Nusantara 2, no. 01 (2018): 72-87.

. "Konsep Etika Religius Ibnu Athā'illah Al-Sakandarī." Asy-Syari'ah : Jurnal Hukum Islam 4, no. 2 (2018): 127-50. https://doi.org/10.36835/assyariah.v4i2.105.

Ghozi, Ghozi. "Landasan Ontologis Dan Kualifikasi Makrifat Ibn 'Atâ' Allâh al-Sakandarî." TEOSOFI: Jurnal Tasawuf Dan Pemikiran Islam 6, no. 1 (3 Juni 2016): 57-91. https://doi.org/10.15642/teosofi.2016.6.1.57-91.

Haris, Abd. Etika Hamka. Yogyakarta: Lkis, 2010.

Iqbal, Abu Muhammad. Pemikiran Pendidikan Islam "Gagasan-Gagasan besar para ilmuan Muslim." 1 ed. Yogyakarta: Pustaka Pelajar, 2015.

Ishari, Nurhafid. "Pendidikan Karakter dalam Kitab Al-Hikam Al- Athā'illah Karya Syeikh Ibnu Athā'illah As-Sakandarī." Jurnal Pendidikan Islam: Tarbiyatuna 10, no. 1 (2017): 66-79.

Kementrian Pendidikan Nasional. Pengembangan Pendidikan Budaya dan Karakter Bangsa. Jakarta: Badan Penelitian dan Pengembangan Pusat Kurikulum, 2010.

Kung, Hans. Islam, Last, Present, and Future. UK, Oxford: Oneworld Publications, 2007.

Mangunhardjana, A. Isme-Isme dari A Sampai Z. Yogyakarta: Kanisius, 1997.

Maragustam. Filsafat Pendidikan Islam Menuju Pembentukan Karakter. Yogyakarta: Pascasarjana. Fakultas Ilmu Tarbiyah dan Keguruan UIN Sunan Kalijaga, 2018.

Masbur. "Internalisasi Nilai-Nilai Pendidikan Perspektif Abraham Maslow (1908-1970); Analisis Filosofis." Jurnal Ilmiah Edukasi 1, no. 1 (2015): 29-47.

Mudin, Moh. Isom. “Konsep Makrifat: Ibnu'Ata'Illah Al-Sakandari.” Jurnal Kalimah 14, no. 2 (2016): 155-72.

Nata, Abudin. Manajemen Pendidikan Mengatasi Kelemahan Pendidikan Islam di Indonesia. Jakarta: Kencana, 2012.

Ninin, Retno Hanggarani. "Diri Religius: Suatu Perspektif Psikologi Terhadap Kepribadian Akhlaqul Karimah." Psikis: Jurnal Psikologi Islami 5, no. 1 (2019): 1-12. https://doi.org/10.19109/Psikis.v5i1.2041.

Omar, Syed Hadzrullathfi Syed, dan Nurul Aarifah Musa. "Pembentukan Ummah Wasatiyyah Menerusi Terapi Tauhid Al-Hikam Shaykh Ibn Ataillah." Jurnal Islam Dan Masyarakat Kontemporari 16, no. 1 (31 Januari 2018): 11-21.

Rahayu, Iin Tri. Psikoterapi Perspektif Islam \& Psikologi Kontemporer. Malang: UINMalang Press, 2009.

Safik, Abduloh. "Distingsi Pemikiran Tasawuf Ibn'Ata'Illah Al-Sakandari." Jurnal Kontemplasi 4, no. 2 (2016): 217-30.

Simuh. Tasawwuf dan Perkembangannya dalam Islam. Jakarta: Raja Grafindo Persada, 1996.

Suwarno, Wiji. Etika Islam dan Produktivitas Menulis Pustakawan Pada Perguruan Tinggi Keagamaan Islam Negeri. Disertasi. Yogyakarta: UIN Sunan Kalijaga Yogyakarta, 2019.

Syari'ati, Ali. Humanisme Antara Islam dan Barat. Jakarta: Pustaka Hidayah, 1992.

Google Docs. "UU_no_20_th_2003 tentang SPN.pdf." Diakses 28 Oktober 2019. https://drive.google.com/file/d/14rj65yvlU8reSd8m2Po3gZVfstD_cg1X/view?usp=sh aring\&usp=embed_facebook.

Yaqzdi, M.T Misbah. Meniru Tuhan: Antara Yang Terjadi dan yang Mesti Terjadi, terj. Ammar Fauzi Heriyadi. Jakarta: al-Huda, 2006. 